\title{
INTEGRALNI PRISTUP UPRAVLJANJU GEOHAZARDIMA NA PODRUČJU KONTAKTA FLIŠA I KRŠA
}

\author{
INTEGRAL APPROACH TO GEOHAZARD \\ MANAGEMENT AT FLYSCH-KARST CONTACT
}

\author{
Sandra Štajdohar*, Sanja Dugonjić Jovančević
}

\begin{abstract}
Sažetak
Na kontaktu flišne stijenske mase i vapnenaca, unutar područja središnje i sjeverne Istre te zaleđa Kvarnera evidentirani su brojni geohazardni događaji, a najznačajniji od njih su pojave nestabilnosti. U radu je dan pregled značajki područja istraživanja ključnih za pojavu ovog tipa geohazarda. Napravljen je pregled recentnih nestabilnosti i njihovih posljedica kako bi se pokazala motivacija za istraživanje, a i potreba za razvojem cjelovitog sustava upravljanja postojećim problemom. Kroz istraživanje je razvijen koncept integralnog pristupa upravljanju geohazardima, a predloženi okvir mogao bi se kroz različite mehanizme integrirati u sadašnji način funkcioniranja i smanjenje posljedica za postojeće elemente rizika. Predloženi pristup zahtijeva opsežne i mnogobrojne analize, ali određeni elementi mogli bi se implementirati bez većih zahtjeva.
\end{abstract}

Ključne riječi: geohazardi, klizišta, upravljanje rizikom, fliš, krš, integralni pristup

\begin{abstract}
At the flysh rock mass and karst contact, in the area of central and northern Istria, as well as Kvarner hinterland, numerous geohazard events have been recorded, the most significant of which the instabilities. This paper gives an overview of the research area key settings, important for this type of geohazards. A review of recent instabilities and their consequences is presented to show the research motivation, as well as the need to develop an integrated management system for managing the existing problem. The concept of an integrated approach for geohazard management has been developed through this research, and the proposed framework could be
\end{abstract}

* Sveučilište u Rijeci, Građevinski fakultet, Radmile Matejčić 3, 51000 Rijeka
E-mail: sandra stajdohar@gmailcom; sanja dugoniic.jovancevic@unirihr 
implemented into the present mode of functioning to reduce the consequences for the existing elements at risk. The proposed approach requires extensive and numerous analysis, but certain elements of this framework could be implemented without major requirements.

Key words: geohazards, landslides, risk management, flysch, karst, integral approach

\section{Uvod}

Riječ hazard je arapskog podrijetla, izvedena od riječi $a z-z a h r$ koja označava igru kockom. Pojam hazard može se definirati kao vjerojatnost pojave bilo koje potencijalno štetne pojave, procesa, stanja ili događaja u prostoru i vremenu, a koji može uzrokovati štetu. Karakteristike hazarda uključuju njegovu prirodu (vrstu), veličinu (mjerilo), vrijeme i trajanje, brzinu, učestalost (broj i prirodu svake epizode), opseg (dimenzije) i povezane naknadne/sekundarne geohazarde. Ovisno o načinu na koji hazard nastaje, razlikujemo geohazarde i antropogene hazarde. Geohazardi nastaju prvenstveno zbog bilo kojeg geološkog događaja, procesa, aktivnosti ili stanja okoliša, a najveći utjecaj imaju u naseljenim područjima, zbog čega se porastom stanovništva povećava i cjelokupni rizik. Istovremeno, nedostatkom prostora za gradnju javlja se potreba za širenjem na područja koja nisu tako pogodna i gdje postoji određeni stupanj podložnosti geohazardu. Na pojavu geohazarda utječu i antropogeni utjecaji pa je u nekim slučajevima teško razlučiti o kojoj je vrsti hazarda riječ.

Pri upravljanju geohazardima važno je započeti s analizom sličnih pojava u prošlosti $\mathrm{i}$ analizom postojećeg stanja. Pritom valja imati na umu da se u literaturi iza analize geohazarda ponekad krije analiza podložnosti, iako je koncepcijski različita od analize hazarda. Podložnost geohazardu je vjerojatnost pojave geohazarda na određenom području uslijed karakterističnih lokalnih uvjeta, dok analiza hazarda sadrži i analizu vremenske vjerojatnosti pojave. Hazard je koncepcijski povezan s rizikom, elementima rizika i njihovom ranjivosti (Slika 1), koji nerazdvojno čine elemente okvira za upravljanje geohazardom. Rizik je mjera vjerojatnosti i težine gubitka za elemente rizika, a označava očekivani broj izgubljenih života, ozlijeđenih osoba, oštećenja imovine i poremećaja gospodarske aktivnosti. Elemente rizika označavaju svi atributi koji imaju svoju vrijednost (stanovništvo, zgrade, gospodarske aktivnosti, javne usluge, komunalne usluge, infrastruktura, fizička i psihička dobrobit, itd.), koji su izloženi riziku na određenom području $[1,2]$. 


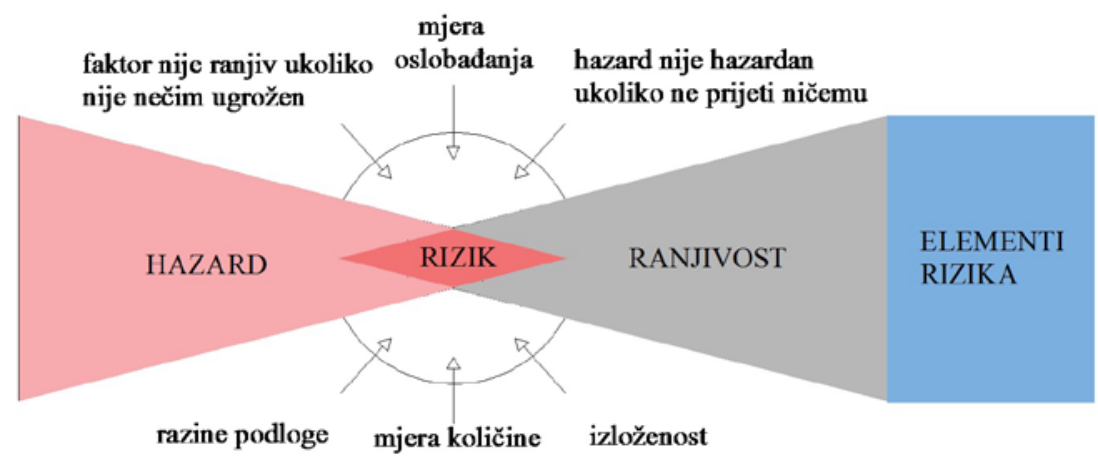

Slika 1. Koncepcijska veza između hazarda, elemenata rizika, ranjivosti i rizika (prema [3])

U radu je provedena identifikacija postojećih geohazarda na području središnjeg i sjevernog dijela Istre, kao i zone u zaleđu Kvarnera koja se proteže dolinom Rječine, Draškom udolinom, padinama oko Bakarskog zaljeva, Bakaračkim rovom i Vinodolskom udolinom. Povijesni podaci i istraživanje lokacije provedeno u sklopu ovog rada ukazuju na najveću prisutnost klizišta kao jednog od tipova geohazarda (na cijelom području istraživanja), zatim na potencijalnu opasnost od potresa (područje zaleđa Rijeke i Vinodola), poplava (u dolini Rječine) i erozije (u Vinodolskoj udolini i Istri).

Specifičnosti područja istraživanja koje će biti detaljnije opisane, kao i preliminarna analiza prisutnih geohazarda, svjedoče da su najbrojnija klizišta, evidentirana iz povijesne dokumentacije, prethodnih istraživanja i obilaska terena, a da inventar klizišta na većini područja nije izrađen. Inventar klizišta izrađen je za dio područja Vinodolske udoline [4]. Pojave klizanja na navedenim područjima istraživane su do sada u brojnim radovima [5-13]. Ta činjenica predstavlja motivaciju za razvojem jednog složenijeg i održivijeg sustava upravljanjem ovim problemom. U radu je pojašnjena metodologija koja predstavlja primjer sustavnog i cjelovitog rješenja upravljanja rizikom klizanja, smanjenja posljedica štetnih događaja, ali i boljeg suživota s postojećim geohazardima.

\section{Prirodne značajke područja istraživanja}

\subsection{Geološke značajke lokacije}

Područje istraživanja, prikazano na Slici 2, obuhvaća sjeverozapadni, jadranski dio geotektonske jedinice Vanjskih Dinarida koji izgrađuju karbonatne stijene krede i paleogena (vapneci, dolomitični vapnenci i breče) te siliciklastične stijene paleogenske starosti (lapori i fliš) [14]. 


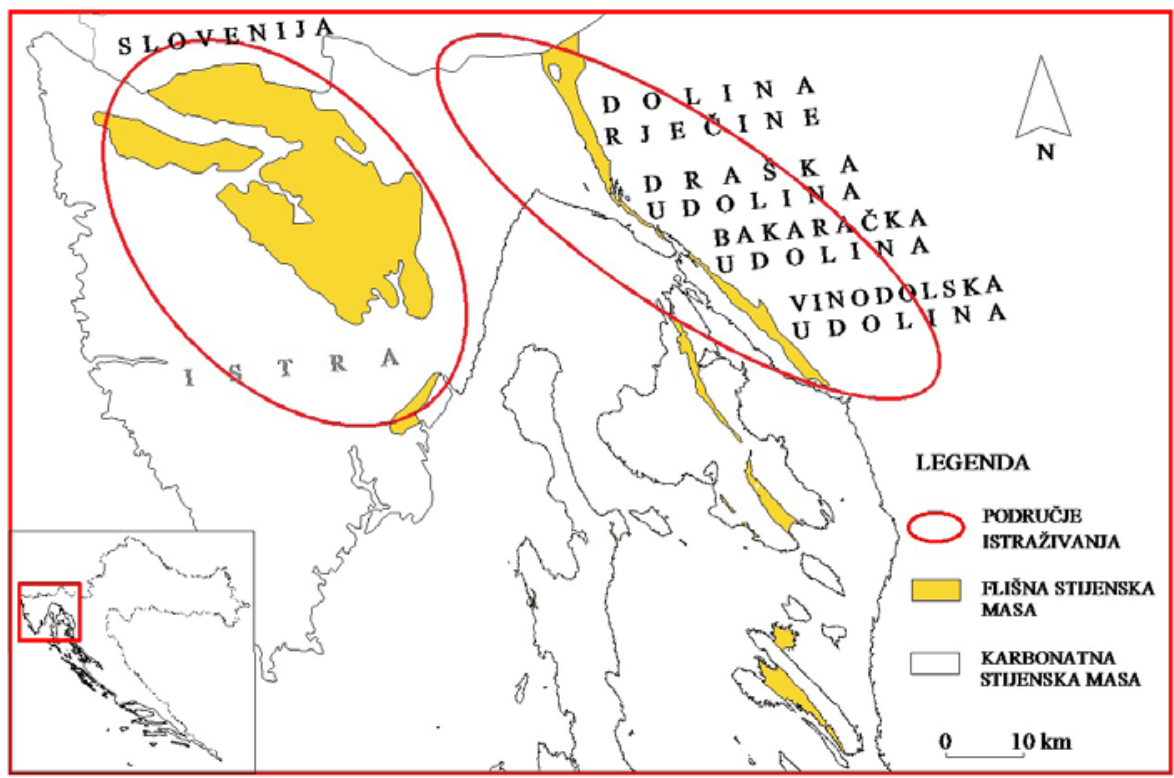

Slika 2. Pojednostavljen prikaz distribucije materijala iz pregledne geološke karte šireg područja istraživanja [15]

Lapori i flišni slijed naslaga protežu se od Tršćanskog zaljeva na zapadu do hrpta Učke na istoku. To je područje Sive Istre. Te sedimentne stijene imaju gotovo horizontalni položaj slojeva, što je pokazatelj njihove slabe tektonske poremećenosti. Nasuprot tomu, u planinskoj skupini Ćićarija (Bijela Istra) nalaze se tektonski jako poremećene gornjokredne i paleogenske stijene sa značajkama ljuskave strukture. Područje planinskog hrpta Učke u geološkom je smislu tektonski jako poremećena i višestruko navučena antiklinalna struktura [16]. U morfološkom razvoju istarskog poluotoka lapori i naslage fliša tvore glavninu stijenske mase koja je u cjelini podložna brzom raspadanju i stoga izrazito erodibilna. Upravo zbog toga, u procesu morfogeneze područja Istre, tijekom pleistocena pa i holocena zbivala se značajna diferencijalna erozija terena izgrađenih od paloegenskih stijena. Na dijelovima terena gdje su više zastupljeni otporniji pješčenjaci, breče i konglomerati stvorena su uzvišenja, dok su se udubljenja u reljefu postupno ispunjena erodiranim sedimentima. U isto vrijeme, na karbonatnim stijenama odvijao se znatno sporiji proces okršavanja. Zbog toga danas karbonatna stijenska masa ima obilježja krša [17].

Drugo područje, obrađeno u ovom radu, je morfostrukturna jedinica koja se proteže od sjeverozapada prema jugoistoku pravcem: Ilirska Bistrica - Klana - dolina Rječine - Sušačka draga - Bakarski zaljev - Vinodolska udolina [14]. Ova geološka struktura može se smatrati flišnom 
sinklinalom ograničenom rasjedima. Na uzvišenjima i gornjim dijelovima padina nalaze se kredni i paleogenski vapnenci koji imaju obilježja krša, a paleogenske siliciklastične stijene (fliš) hipsometrijski niže, uključivši i dio doline (Slika 3). Fliška osnovna stijena odlikuje se velikom litološkom heterogenošću zbog čestog vertikalnog i lateralnog izmjenjivanja raznovrsnih litoloških članova kao što su lapori, siltiti, šejlovi i sitnozrnasti pješčenjaci [8]. Opisana morfostrukturna jedinica dio je seizmotekotnski aktivne zone, gdje su tijekom posljednja dva tisućljeća zabilježeni potresa magnitude do $M=6$ prema Richterovoj ljestvici [18]. Postoje ozbiljne indikacije da su snažni potresi inicirali korete masa na padinama oko doline Rječine [11].
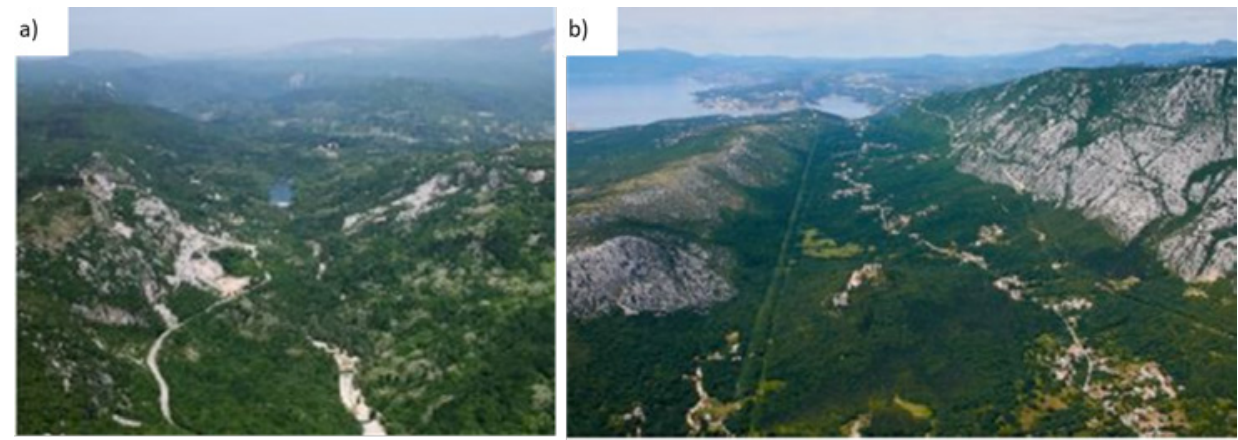

Slika 3. Dolina Rječine (foto Arbanas Ž., 2012.) a),

Vinodolska udolina (foto Kalajžić D., 2015.) b)

\subsection{Hidrološke i hidrogeološke značajke}

Srednje mjesečne oborine s 12 mjernih postaja uključenih u analizu (MP u Istri- Abrami, Rakitovec, Vodice, Lanišće, Lupoglav, Pazin u razdoblju 1961. do 2010.; MP u dolini Rječine- Kozala, Marčelji, Hreljin i MP u Vinodolskoj udolini- Crikvenica, Novi Vinodolski, Bribir u razdoblju od 1961. do 2014.) omogućuju usporedbu količina oborina na području istraživanja (Slika 4).

Najveće količine oborina zahvaćaju područje doline Rječine, koje ima prosječnu godišnju količinu oborina oko $1750 \mathrm{~mm}$. Gledano prosječno na svim mjernim postajama, u razdoblju od siječnja do kolovoza te kroz mjesec prosinac, Istru zahvaća više oborina od Vinodolske udoline, 1400 naprema 1280 mm godišnje. U rujnu i listopadu, Vinodolska udolina je kišovitija od Istre. Može se vidjeti da je na cijelom području istraživanja mjesec s najmanje oborina srpanj, a najkišovitiji je mjesec studeni, s prosječnom količinom oborina 163,1 mm u Istri, 226,1 mm u dolini Rječine i 162,7 mm u Vinodolskoj udolini [19]. Važno je spomenuti da se tipično najviše klizišta događa krajem jeseni i početkom zime, nakon najkišnijih mjeseci. 


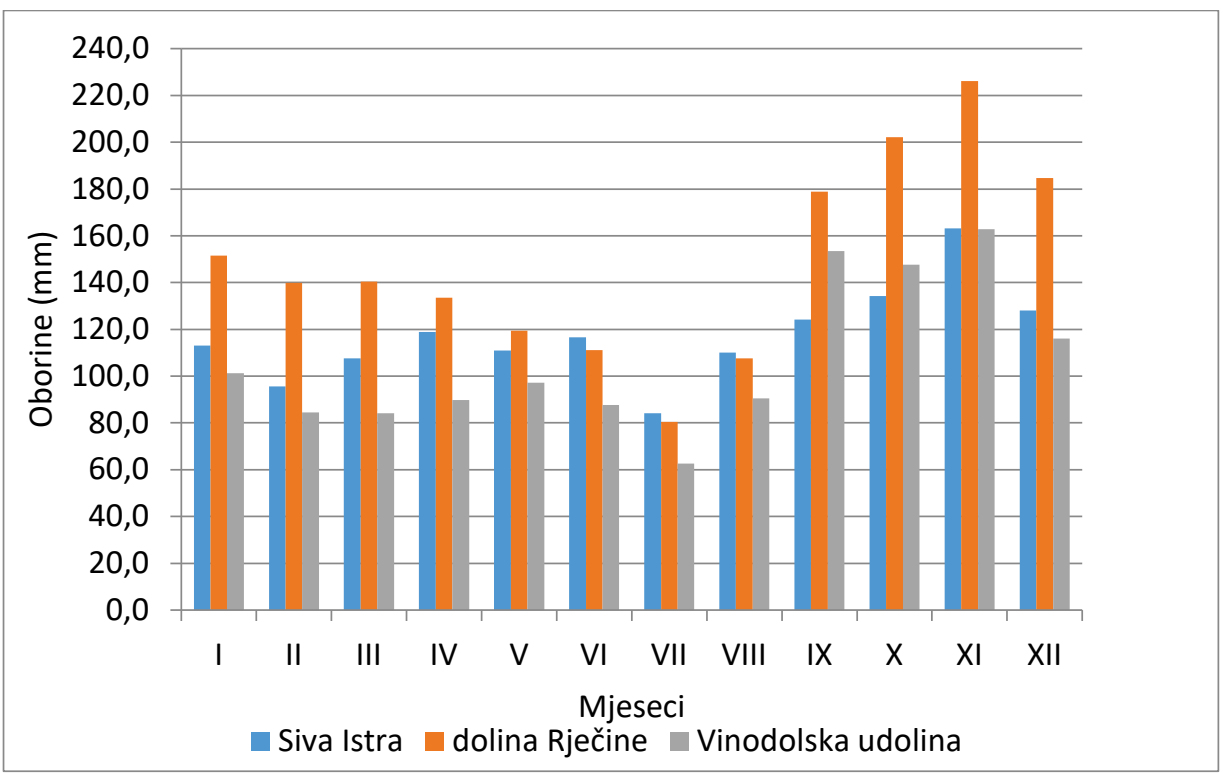

Slika 4. Srednje mjesečne količine oborina na području istraživanja (prema podacima s 12 mjernih postaja)[19]

Karbonatne stijene i flišna stijenska masa razlikuju se u načinu infiltracije oborine, kretanja površinske i podzemne vode, što je ključno za pojave klizišta. Karbonatne stijene su izrazito vodopropusne pa je trajni protok površinskih voda vrlo rijetka pojava. Zbog vodopropusnosti krša, ali i podzemnih oblika vapnenaca, oborine se relativno brzo procjeđuju kroz kršku površinu, prema krškim izvorima podzemne vode, nakon čega ponovno izlaze na površinu. S obzirom da se veličina pukotina i krških kanala razlikuje, krš je obilježen velikom raznolikošću protoka i skladištenja vode. Izvori su veoma važne točke za proučavanje krških podzemnih voda budući da se one mogu izravno promatrati te se njihove karakteristike odražavaju na karakteristike krškog vodonosnika [20]. Fliš, s druge strane, uglavnom karakterizira vodonepropusnost, često površinsko zadržavanje vode (Slika 5.a) i periodično površinsko tečenje tijekom kišnog razdoblja koje ima erozijsko djelovanje $[13,20]$. To je značajno jer su erodirana područja podložna daljnjim nestabilnostima (Slika 5.b). 

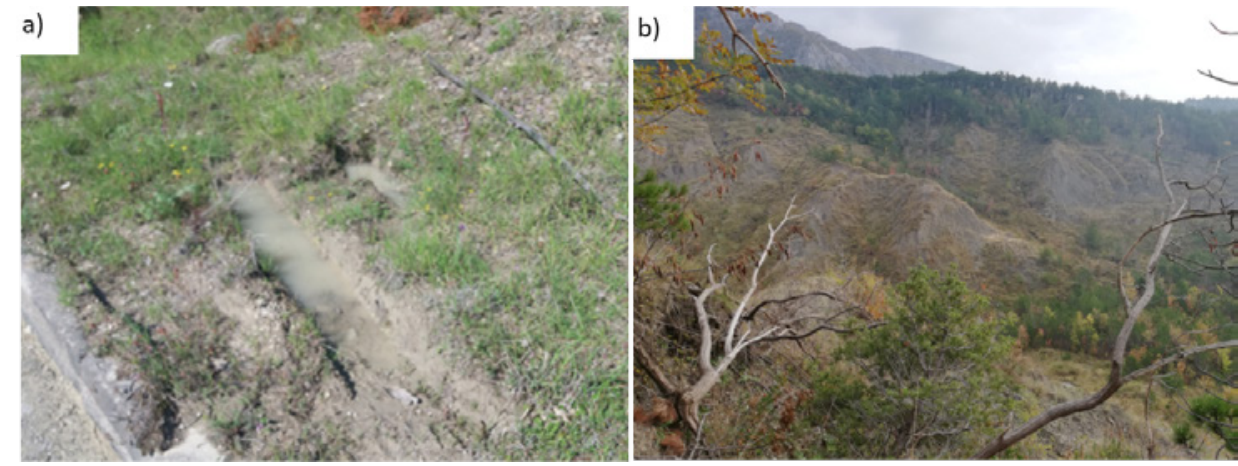

Slika 5. Flišna stijenska masa na području istraživanja: a) zadržavanje oborine na površini (Istra), b) erozijsko djelovanje (Slani potok, Vinodolska udolina)

\subsection{Klizišta na istraženim područjima}

Geološka svojstva karbonatnih stijena, važna za formiranje krša, uključuju primarnu i sekundarnu poroznost karbonatnih stijena, njihov mineraloški sastav, veličinu zrna, teksturu, debljinu sloja i stupanj tektonske deformacije. Flišna stijenska masa, s druge strane, odlikuje se litološkom heterogenošću zbog čestog vertikalnog i lateralnog izmjenjivanja različitih litoloških članova kao što su lapori, siltiti i sitnozrnasti pješčenjaci. Flišna stijenska masa spada u meke stijene, slabe je vodopropusnosti, izrazito podložna trošenju i eroziji te je stoga gotovo u potpunosti prekrivena trošnim površinskim materijalom sastavljenim od mješavine gline, praha, pijeska i odlomaka do blokova pješčenjaka različite debljine. Karakteristično je trošenje nekompetentnih članova flišne stijenske mase (lapori i siltiti) i veća otpornost trošenju kompetentnih članova kao što su pješčenjaci [21]. U Sivoj Istri često su prisutne ogoline flišne stijenske mase za koje je karakterističan niži stupanj trošnosti i izrazito siva boja po čemu je to područje i dobilo ime. Udio pješčenjaka u flišnom kompleksu opada krećući se prema istočnom dijelu područja istraživanja tj. Vinodolskoj udolini. Klizišta se uglavnom događaju na flišnim padinama, na kontaktu koluvija i svježe stijenske mase u podlozi. Na području Istre su tipična manja i plitka rotacijska i translacijska klizanja [12, 13]. U dolini Rječine međutim ima povijesnih klizanja koja su zahvatila i nekoliko milijuna $\mathrm{m}^{3}$ materijala [22]. Česti su odroni vapnenačke stijenske mase i prevrtanje većih blokova, dok su pojave blatnog toka na ovim područjima rijetke [8]. U Vinodolskoj udolini prevladavaju plića klizanja unutar pokrivača i česti odroni na stijenskim liticama [4].

Klizišta se javljaju zato što kontakt s karbonatnim strukturama uvjetuje dublju i intenzivniju infiltraciju oborinskih voda te njihovo dreniranje duž nepropusne flišne stijenske podloge. Najčešći inicijatori klizanja su velike količine oborina u dužem vremenskom razdoblju [12], koje 
infiltracijom uzrokuju porast razine podzemne vode, pri čemu se javljaju hidrodinamičke sile kroz pokrivač niz kosinu te povećanje pornih pritisaka i posljedični pad posmične čvrstoće, a na kraju i slom materijala u padini. Jedan od ciljeva integralnog pristupa ovom problemu bio bi i uspostavljanje vrijednosti oborine koja pokreće klizanje kao eventualni indikator za sustav ranog upozoravanja. S druge strane, kada oborinska voda ponire sa zatvorenih flišnih slivova u krške vodonosnike i nastavlja podzemni tok, unosi sa sobom čestice trošne flišne stijenske mase te aktivira ranije nataložene sitnozrnaste čestice u podzemlju, što rezultira neprihvatljivom razinom mutnoće izvorske vode [23].

\section{Metodologija istraživanja}

Za izradu pouzdane karte pomoću koje možemo predvidjeti opasnost od klizišta u budućnosti, ključno je imati uvid u prostornu raspodjelu i učestalost klizišta na određenom području. Zbog prije navedenog, svaka analiza rizika započinje izradom inventara klizišta koji bi trebao sadržavati prostorne i vremenske podatke o pojedinom klizištu, a što predstavlja dugotrajan i opsežan posao. Kako bi se ukazala potreba za razradom metodologije upravljanja rizikom klizanja na području istraživanja, u fazi identifikacije geohazarda, izrađen je preliminarni prostorni inventar pojave klizišta koji daje uvid u prostornu distribuciju aktivnih i saniranih klizišta (Slika 7). Za potpunost inventara potrebno je svako klizište prikazati odgovarajućim poligonom, pridružiti informacije o tipu, veličini i vremenu klizanja. Dio klizišta u Sivoj Istri, Dolini Rječine, Draškoj, Bakaračkoj i Vinodolskoj udolini preuzet je iz postojećih inventara, daljinskih istraživanja dijela područja i projektne dokumentacije saniranih klizišta. Klizišta koja se nalaze u Sivoj Istri preuzeta su iz doktorskog rada [12,13] i obuhvaćaju pojave dokumentirane iz postojećih projekata sanacije, ali i stereoskopske analize područja oko Grada Buzeta. Klizišta na prometnici Cerovlje-Buzet u Istri utvrđena su geomorfološkom terenskom analizom [24]. Klizišta u Dolini Rječine preuzeta su iz prikupljenih podataka o postojećim i povijesnim klizanjima [11, 22, 25]. Klizišta u Bakaračkom rovu preuzeta su iz rada [26] u kojem su kartirana prema povijesnim podacima i obilasku terena, dok su klizišta u Draškoj udolini evidentirana iz podataka o lokacijama saniranim tijekom izgradnje riječke zaobilaznice. Lokacije klizišta u Vinodolskoj udolini preuzete su iz znanstvenog rada [27], iako je poznato da je na tom području evidentirano 633 klizišta vizualnom interpretacijom digitalnoga modela reljefa Vinodolske udoline [4]. Prikupljeni podaci o klizištima dopunjeni su terenskim obilaskom dijela prometnica u Sivoj Istri i geomorfološkom interpretacijom znakova klizanja na terenu (prisutne vlačne pukotine, denivelacija i oštećenja prometnica, ulegnuća, brežuljkaste padine, nagnuto drveće, neobično procjeđivanje i utvrđena veća količina vode (Slika 6). 


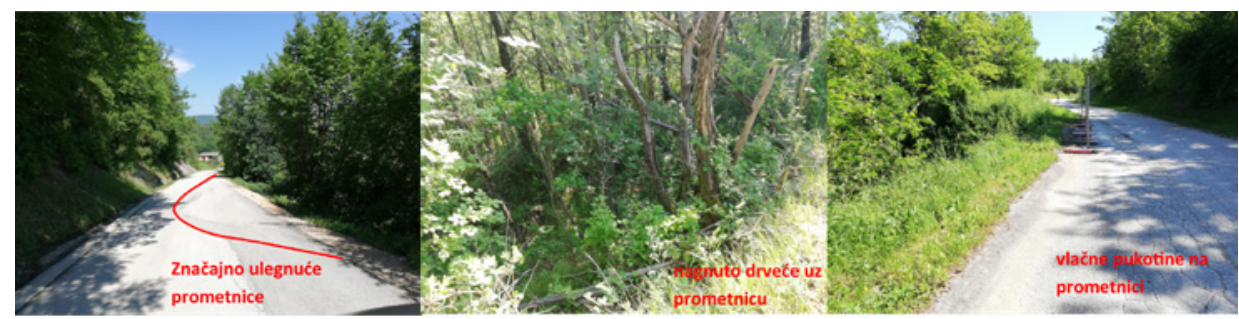

Slika 6. Vidljivi znakovi klizanja pri terenskom istraživanju u Sivoj Istri

Nakon izrade preliminarnog inventara klizišta, po uzoru na međunarodno prihvaćenu proceduru razrađen je okvir upravljanja rizikom klizanja na području istraživanja. Kako bi se opravdalo razmatranje predloženog okvira, preliminarni inventar klizišta preklopljen je s postojećim prostornim planovima (Istarska i Primorsko-goranska županija).

\section{Rezultati preliminarnog istraživanja distribucije najučestalijeg geohazarda}

Najviše klizišta evidentirano je na području Sive Istre (otprilike 110 klizišta), od kojih je nekoliko saniranih (manje od 10) gabionskim zidom, armirano betonskim potpornim zidom, obložnim zidom ili je saniran dio padine uz prometnicu. Također, evidentirana su i poneka umirena klizišta. U dolini Rječine nalazi se 10 klizišta, s tim da većina i dalje predstavlja prijetnju zbog česte reaktivacije klizišta u tom području. U Draškoj udolini evidentirana su četiri sanirana klizišta, oko Bakra tri klizišta, a u Vinodolskoj udolini 48 klizišta, od kojih se 35 klizišta nalazi u zonama intenzivne erozije s najvećom gustoćom klizišta i 16 u blizini naselja, što uzrokuje stalnu štetu na cesti i građevinama (Slika 7).

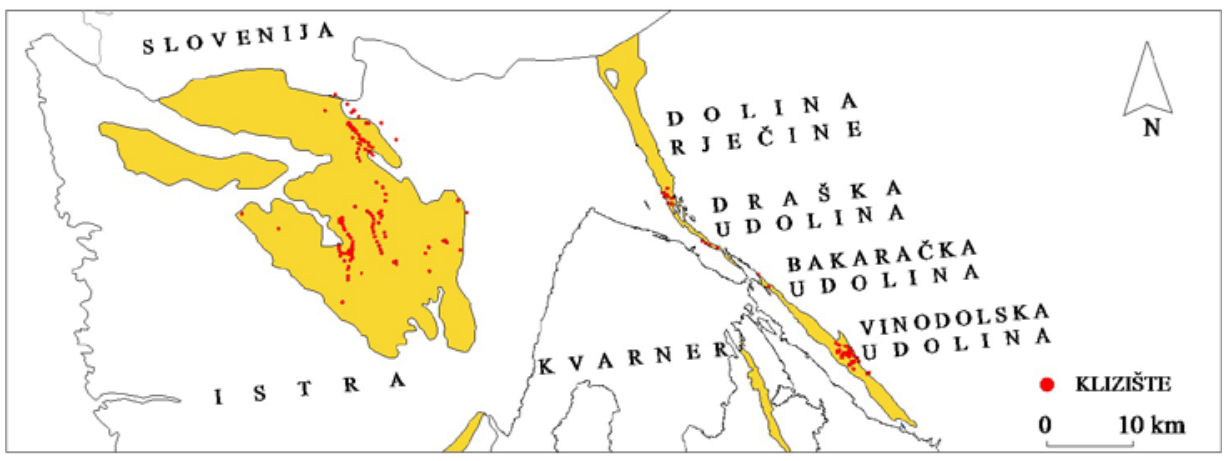

Slika 7. Preliminarni inventar klizišta na području istraživanja [19] 
Preklapanjem preliminarnog inventara klizišta $\mathrm{s}$ prostornim planovima na području istraživanja dobio se uvid o prisutnim elementima i potencijalnoj razini rizika. Prema namjeni površina iz prostornog plana Istarske županije [27], površine koje su zahvaćene klizištima uključuju: prometnice, živice i šikare kontinentalnih i primorskih krajeva, primorske termofilne šume i šikare medunca, nasade četinjača, površine obrasle korovom i ruderalnom vegetacijom, aktivna seoska područja, intenzivno obrađivane oranice na komasiranim područjima, infralitoralna čvrsta dna i stijene te naselja. Kao najbitnije, izdvajaju se urbanizirana seoska područja i aktivna seoska područja budući da su naseljena, što znači da postoje izuzetno ranjivi elementi rizika [19]. Analiza prostornog plana Primorskogoranske županije [28] pokazala je da se klizišta koja zahvaćaju područje Vinodola, doline Rječine, oko Bakarskog zaljeva i Bakaračkog rova nalaze u neposrednoj blizini područja za koja su napravljeni urbanistički i detaljni planovi uređenja, a evidentno je da ugrožavaju brojne prometnice na tom području [19].

\section{Okvir za upravljanje rizikom klizanja}

\subsection{Međunarodno prihvaćeni okvir}

Predloženi okvir upravljanja rizikom prati međunarodno prihvaćeni okvir [29], u kojem prvi korak predstavlja analiza rizika koja uključuje analizu hazarda i analizu posljedica. Prvi korak u analizi hazarda je identifikacija prisutnog geohazarda. Detaljno razumijevanje prošlih događaja i njihovog učinka pruža osnovu za razumijevanje onoga što bi se moglo dogoditi u budućnosti. Identifikacija se provodi tako da se potencijalni geohazardi prepoznaju i okarakteriziraju (mehanizmi, magnituda, uzročni faktori, pokretači i dr.), nakon čega se provodi procjena učestalosti. Kod analize posljedica potrebno je definirati prisutne elemente rizika i njihovu ranjivost, nakon čega se provodi analiza vjerojatnosti i ozbiljnosti posljedica. Rizik se ocjenjuje s obzirom na kriterij tolerancije i procjenu vrijednosti na način da se procijenjeni rizik usporedi s kriterijima tolerancije, a nakon čega se određuju prioritetni rizici za kontrolu i praćenje. Krajnji cilj metodologije je uspostava odgovarajućeg rješenja upravljanja rizikom kojim se postojeći rizik umanjuje ili svodi na najmanju moguću mjeru. Ovaj korak uključuje identifikaciju opcija za smanjivanje rizika koje se smatraju prihvatljivima (uključuju i tekuće praćenje i održavanje), odabir opcija s najvećim učinkom smanjenja rizika uz najmanje troškove, implementaciju rješenja te procjenu preostalog rizika. Ukoliko se opcija ne pokaže zadovoljavajućom, potrebno je provesti analize pomoću kojih će se doći do boljeg rješenja. 


\subsection{Prijedlog integralnog okvira za upravljanje rizikom klizanja na području istraživanja}

Rezultati identifikacije prisutnih klizišta ukazuju na potrebu sprječavanja ili umanjivanja rizika od klizanja kroz širi i cjelovitiji pristup upravljanju koji zahtijeva opsežnu i sustavnu analizu, ali i uključivanje brojnih subjekata te njihovo interdisciplinarno djelovanje s istim ciljem. Stoga je u nastavku razrađen prijedlog integralnog okvira upravljanja rizikom klizanja (Slika 8). Važno je naglasiti da okvir odgovara korištenju i kvalitativne i kvantitativne metodologije u analizi hazarda i rizika [1]. Prethodno uvođenju bilo kakvog složenijeg sustava upravljanja potrebno je utvrditi sadašnju razinu upravljanja, razinu informiranosti i potrebe za drugačijim upravljačkim sustavom. Stoga se predlaže provođenje upitnika unutar upravljačke zajednice i lokalnog stanovništva. Upitnikom bi se saznalo jesu li geohazardi uključeni u prostorno planiranje, uzimaju li se pri planiranim zahvatima u obzir karakteristike geološke građe na lokaciji, na koji način se u praksi pristupa sanaciji klizišta, koliki su godišnji troškovi, kako su osigurana sredstva, koliko ispitane strukture poznaju sustave monitoringa, ranog upozoravanja i druge moguće mjere smanjenja rizika. Ključno je od lokalnog stanovništva utvrditi razinu informiranosti o stupnju opasnosti, mogućnostima zaštite, evakuacije, poznavanju mjera upozoravanja i slično.

Prva glavna cjelina okvira za upravljanje rizikom (Slika 8) je analiza rizika, koja započinje s utvrđivanjem povijesti hazarda. Drugi korak odnosi se na identifikaciju hazarda gdje su vrlo bitni prostorni podaci (lokacija hazarda), kao i vremenska učestalost njegove pojave. Budući da su klizišta pojave koje se uvijek događaju kombinacijom više uzročnih faktora, vrlo je bitno prilikom identifikacije utvrditi glavne faktore povezane s klizanjem. $\mathrm{Na}$ osnovi prikupljenih podataka izrađuje se privremena bazu podataka o klizištima i parametrima koji utječu na njihovo pojavljivanje. Većinom se u tom koraku koriste sateliti, dronovi ili digitalni elevacijski modeli koji omogućavaju daljnju analizu faktora koji utječu na pojavu klizišta (faktorske karte: nagiba, visine, orijentacije, litološke građe itd.). Kako bi se osiguralo pravovremeno obavještavanje o hazardima, bitno je razviti funkcionalan i točan sustav monitoringa i nadzora koji obavještava o pojavi novih hazarda ili reaktivaciji već prisutnih. U izvještavanju o novim hazardima javnost također može pomoći. Uključenost znanstvene zajednice koja se bavi istraživanjima klizišta kroz studije, laboratorijska i terenska ispitivanja vrlo je važna. Interakcijom svih dionika uključenih u problematiku kontinuirano se ažurira baza podataka o klizištima. Prilikom izrade inventara preporuka je da se koristi GIS (Geografski Informacijski Sustav) zato što je dovoljno jednostavan za primjenu na velikim područjima, a omogućuje sustavno pohranjivanje i obradu podataka o svakom klizištu, kako njegove lokacije, tako i njegove veličine, tipa i svih drugih karakteristika, podataka o faktorima koji utječu na klizanje, kao i vrlo jasan kartografski prikaz rezultata analize. 


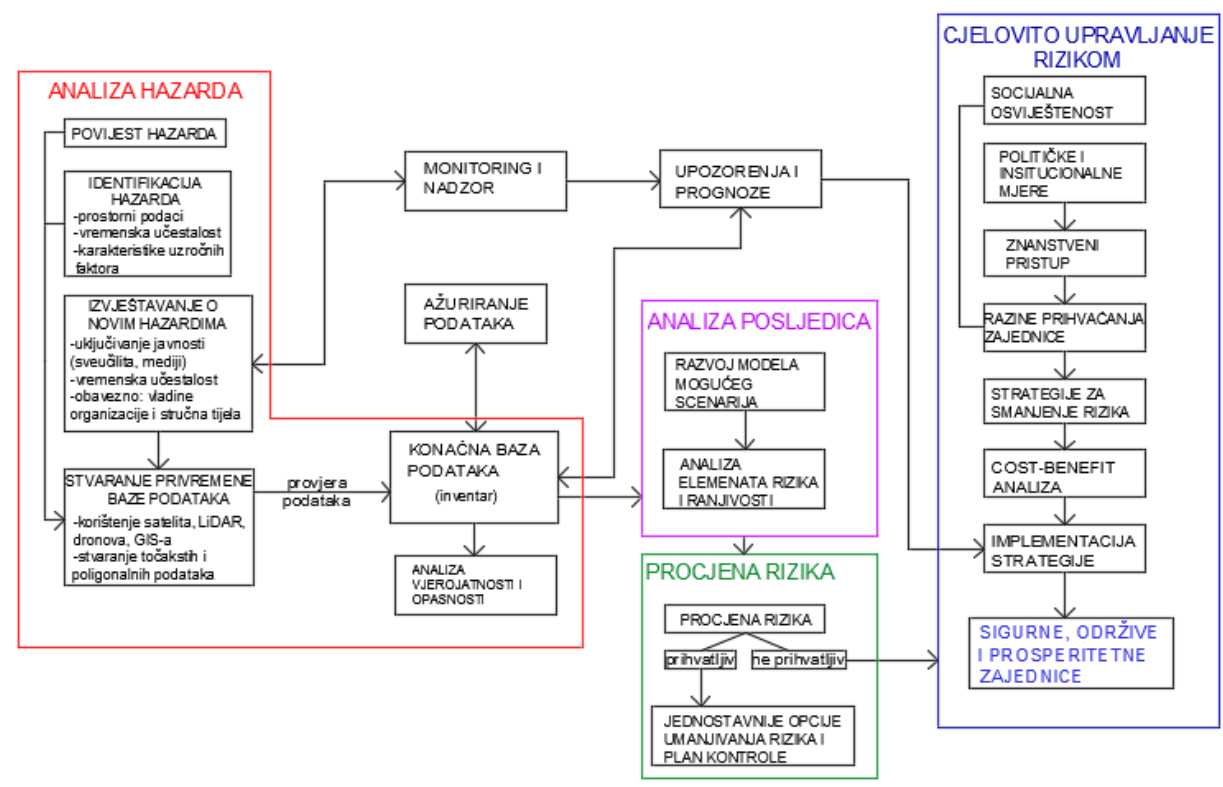

Slika 8. Predloženi okvir upravljanja rizikom [19]

Konačan cilj izrade baze podataka i faktorskih karata je izrada karte hazarda klizanja. $\mathrm{Na}$ osnovu dobivenih podataka o prostornoj distribuciji klizišta potrebno je provesti analizu vjerojatnosti pojave klizišta (uzrokovanu oborinom, potresom ili nečim drugim) tj. analizu hazarda. Analiza hazarda je nezaobilazna za daljnju analizu posljedica (analizu rizika) te procjenu rizika pa zatim i za upravljanje rizikom. Analiza posljedica započinje razvojem modela mogućeg scenarija i njegovog utjecaja na područje istraživanja. S obzirom na veličinu i vrstu događaja, mjerilo događaja i element koji je u opasnosti, provodi se analiza ranjivosti. Na ranjivost elemenata rizika utječu različiti faktori, a između ostalog životna dob, ekonomska situacija, postojeći oblici zaštite, planovi za izvanredne situacije, itd. U većini je slučajeva razina obrazovanja stanovništva, vezana uz pojavu geohazarda, rizika, a posebice vezana za mjere upravljanja rizikom, vrlo niska, odnosno nedostatna. Edukacija stanovništva vodi do određene razine prihvaćanja i smanjenja njezine ranjivosti (informirano i upućeno stanovništvo će bolje, brže i spremnije reagirati). Procjena očekivanih gubitaka dobiva se kombiniranjem fizičke izloženosti elemenata rizika postojećem hazardu.

Svi dosadašnji koraci čine ulazne podatke za procjenu rizika, prilikom koje se ocjenjuje njegova prihvatljivosti. Procjena prihvatljivosti uključuje donošenje odluka o prioritetima, o umanjivanju i kontroli rizika i mjerama svođenja njegove razine na minimum. Prema predloženoj 
metodologiji, ukoliko se utvrdi da je rizik prihvatljiv, predlaže se usvajanje i primjena jednostavnijih opcija umanjivanja rizika i plan kontrole. Ukoliko se uspostavi da rizik nije prihvatljiv, potrebno je provesti cjelovito upravljanje rizikom [19]. Poželjno je uspostaviti sustave za praćenje klizišta te sustave ranog upozorenja koji olakšavaju pravovremeno i točno predviđanje događaja, kao i smanjenje njegovih posljedica, što je ključno u okviru upravljanja rizikom. Razvoj i primjena učinkovitog sustava praćenja, upozorenja i uzbunjivanja temeljenog na znanstvenim spoznajama pomoći će u smanjenju izloženosti geohazardima i suočavanju s neizbježnim katastrofama. Osim jačanja znanstvenih istraživanja vezanih uz geohazarde, također je važno uspostaviti poseban sustav upravljanja rizikom na državnoj razini te definirati uloge, odgovornosti i postupke različitih dionika za smanjenja rizika od prirodnih hazarda. Provedivi i društveno prihvatljivi planovi upravljanja rizicima moraju se provoditi kroz sudjelovanje zajednice, upravljanje, administraciju, političke i institucionalne, kao i financijske sustave te znanstveni pristup [30].

Svrha cjelovitog upravljanja rizikom je njegovo sprječavanje (u mjeri u kojoj je to moguće) ili svođenje na najmanju moguću mjeru. Takav okvir podrazumijeva planiranje, donošenje i provođenje odluka i mjera na svim područjima povezanim s postojećim hazardom. Nastojanja za sprječavanje i umanjivanje rizika moraju biti uključena u polazišta, pripremu, usvajanje i provedbu svih važnijih strategija, planova, programa i propisa. Kao što je ranije spomenuto, održivo rješenje uključuje socijalnu osviještenost i osnaživanje ugroženih zajednica te njihovo uključivanje u informiranje i procese donošenja odluka. Nužno je postojanje političke volje koja će se očitovati u potrebi za analizom geohazarda na regionalnoj, državnoj i međunarodnoj razini te provođenju mjera za njihovo smanjivanje. Efikasnost primjene mjera za cjelovito upravljanje rizikom ovisi o svima uključenim u neku od razina međunarodnog okvira. S obzirom na već prikazane prostorne planove, može se zaključiti da je prostorno planiranje također važna komponenta upravljanja rizikom. Bitno je procijeniti moguće geohazarde i njihov utjecaj na okoliš, stanovništvo i infrastrukturu te na osnovu toga propisati nužne zaštitne mjere, uključivo i promjenu mjesta razmatrane djelatnosti u dijelove manje osjetljivog područja.

Nakon što se predloži nekoliko strategija smanjenja mogućeg rizika, važno je na temelju analize odabrati najbolju koja će biti funkcionalna, a koja će putem pozitivnih rezultata, opravdati troškove. U sklopu takvog odlučivanja provodi se cost benefit analiza procjene moguće štete koju može prouzročiti geohazard te mjere kojima se sprečavaju takvi neželjeni učinci. Usporedbom posljedica i unaprijed određenih mjerila može se odabrati rješenje koje zadovoljava postavljene ciljeve. Nakon provedenih analiza slijedi implementacija odabrane strategije cjelovitog upravljanja rizikom koja vodi do sigurne, održive i prosperitetne zajednice. 


\section{Zaključak}

Strategijom održivog razvoja dugoročno se usmjerava upravljanje određenim rizikom te zaštita ugroženih područja. Prethodno je potrebno utvrditi trenutnu razinu upravljanja kako bi se uvidjelo postoji li potreba za uvođenjem složenijeg sustava. Iz prikupljenih podataka, postojećih i tekućih istraživanja te istraživanja provedenih u sklopu ovog rada može se zaključiti da na području istraživanja postoje elementi koji opravdavaju uvođenje cjelovitog pristupa upravljanju rizikom od klizanja. Cilj je izraditi bazu podataka na osnovu koje se procjenjuje rizik i nakon čega se određuje potreba za uvođenjem cjelovitog upravljanja rizikom. Svrha načela cjelovitog upravljanja je sprječavanje rizika od geohazarda ili svođenje na najmanju moguću mjeru. Predloženi okvir zahtijeva planiranje, donošenje i provođenje odluka i mjera na svim područjima, prilikom čega je najvažnija stavka da svi navedeni elementi okvira budu uspostavljeni i povezani te da postoji zadovoljavajuća razina prihvaćanja zajednice. Cost benefit analizom mogla bi se utvrditi opravdanost uvođenja takvog okvira koji uključuje vrlo opsežne analize, stručnjake iz različitih područja, financijska sredstva i tehničke sustave, političke, sociološke i institucionalne mjere.

Zahvala. Ovaj je članak rezultat rada u okviru inicijalne potpore Sveučilišta u Rijeci "Analiza stijenske mase i pojava nestabilnosti na kontaktu krša i fliša" (18.06.2.1.01.).

\section{Literatura}

[1] Crozier, M.J. i Glade, T. (2005) Landslide Hazard and Risk: Issues, Concepts and Approaches, Landslide Hazard and Risk, Glade T, Anderson M, Crozier MJ (eds.), John Wiley \& Sons, New York, 1-40.

[2] Bell, F.G. (2003) Geological Hazard. Their Assesment, Avoidance and Mitgation. Spon Press, London-New York.

[3] Alexander, D. (2002) Principles of Emergency Planning and Management. Chapter 1: Aims, Purpose and Scope of Emergency Planning, University of Massachusetts.

[4] Đomlija, P. (2018) Identifikacija i klasifikacija klizišta i erozije vizualnom interpretacijom digitalnoga modela reljefa Vinodolske udoline. Doktorska disertacija. Rudarsko-geološko-naftni fakultet. Sveučilište u Zagrebu.

[5] Benac, Č., Jurak, V., Oštrić, M. (2005) Qualitative Assessment of Geohazard in Rječina Valley, Croatia. Geophysical Research Abstract, Vol. 7, 08943, 1-6, 2005.

[6] Benac, Č., Jurak, V., Arbanas, Ž., Oštrić, M., Ožanić, N. (2005) Complex Landslide in the Rječina River Valley (Croatia): Origin and Sliding Mechanism. Bulletin of Engineering Geology and the Environment 64(4): 361-371. 
[7] Arbanas, Ž., Benac, Č., Jurak, V. (2006) Causes of Debris Flow Formation in Flysch Area of North Istria, Croatia. In: Monitoring, Simulation, Prevention and Remediation of Dense and Debris Flows (Lorenzini, G., Brebbia, C.A. \& Emmanouloudis, D.E., eds.), WIT Transaction on Ecology and the Environment, 90, 283-292.

[8] Benac Č., Dugonjić, S., Arbanas Ž., Oštrić, M., Jurak, V. (2009) The Origin Of Instability Phenomena Along The Karst-Flysch Contacts. ISRM International Symposium Rock Engineering in Difficut Ground Conditions: Soft Rock and Karst, October, 2009, Cavtat (Vrkljan, I. ed.), 757-761. CRC Press, Boca RatonLondon-New York- Leiden.

[9] Arbanas, Ž., Dugonjić, S. , Benac, Č. (2011) Causes of Small Scale Landslides in Flysch Deposits of Istria, Croatia. Abstract Book of the Second World Landslides Forum (Catani, F., Margottini, C. Trigila, A., Ladanza, C. eds.). ISPRA - Italian National Institute for Environmental Protection and Research, Roma.

[10] Dugonjić Jovančević, S., Arbanas, Ž., Benac, Č., Mihalić, S. (2012) Landslide Susceptibility Analyses in Flysch Areas in the North-Eastern Part of the Adriatic Coast. In: Risk Analysis VIII: Proceedings of 8th International Conference on Simulation in Risk Analysis and Hazard Mitigation, Brač, september 2012. (BREBBIA, C., ed.), 237-248. WIT Press, Southampton.

[11] Vivoda, M., Benac, Č., Žic, E., Đomlija, P., Dugonjić Jovančević, S. (2012) Geohazard u dolini Rječine u prošlosti i sadašnjosti. Hrvatske vode 81, 105116.

[12] Dugonjić Jovančević, S., Arbanas, Ž. (2012) Recent Landslides on the Istrian Peninsula, Croatia, Natural hazards. Vol.62, 3; pp 1323-1338.

[13] Dugonjić Jovančević, S. (2013) Procjena hazarda pojave klizanja u flišu. Doktorska disertacija. Građevinski fakultet. Sveučilište u Rijeci.

[14] HGI (2009) Geloška karta Republike Hrvatske 1:300.000. Hrvatski geološki institut, Zagreb.

[15] Velić, I. i Vlahović, I. (2009) Geološka karta Republike Hrvatske 1:300.000, Geološki institut, Zagreb.

[16] Vlahović, I., Tišljar, J., Matičec, D., Velić, I. (2005) Geologija. Istarska enciklopedija, (ur. Bertoša, M., Matijašić, R.), 246-249. Leksikografski zavod Miroslava Krleže, Zagreb.

[17] Benac, Č., Rubinić, J., Ružić, I., Radišić, M. (2017) Geomorfološka evolucija riječnih dolina i ušća na istarskom poluotoku. Hrvatske vode 100, 71-80.

[18] Herak, M., Herak, D., Markušić, S. (1996) Revision of the Earthquake Catalogue and Seismicity of Croatia,1902-1992. Terra Nova, 8, 86-94.

[19] Štajdohar, S. (2019) Integralni pristup upravljanja geohazardom na području kontakta fliša i krša, Diplomski rad, Građevinski fakultet Sveučilišta u Rijeci.

[20] Zupan Hajna, N., Ravbar, N., Rubinić, J., Petrič, M. (2015) Life and Water on Karst: Monitoring of Transboundary Water Resources of Northen Istria. Slovenija, Hrvatska. 
[21] Vivoda Prodan, M. (2016) Utjecaj trošenja na rezidualnu posmičnu čvrstoću sitnozrnastih litoloških članova fliša. Doktorska disertacija. Građevinski fakultet. Sveučilište u Rijeci.

[22] Arbanas, Ž., Mihalić Arbanas, S., Vivoda, M., Peranić, J., Dugonjić Jovančević, S., Jagodnik, V. (2014) Identification, Monitoring and Simulation of Landslides in the Rječina River Valley, Croatia, Proceedings of the SATREPS Workshop on Landslide Risk Assessment Technology, Sassa, Kyoji ; Dang, Khang Q. (ur.). Kyoto: International Consortium on Landslides. 200-213.

[23] Dugonjić Jovančević, S., Rubinić, J., Ružić, I., Radišić, M. (2018) Utjecaj fliških i krških struktura na dinamiku protjecanja podzemnih voda i pojavu ekstremnih situacija u slivu izvora sv.ivan u istri, Hidrologija u službi zaštite i korištenja voda te smanjenja poplavnih rizika-suvremeni trendovi i pristupi (Rubinić, J.; Ivanković, I.; Bušelić, G. ur.). Zagreb: Hrvatsko hidrološko društvo, 201-204.

[24] Zidarić, M. (2015) Tragovi klizanja na prometnici Cerovlje-Buzet u Istri, Diplomski rad. Građevinski fakultet. Sveučilište u Rijeci.

[25] Dugonjić Jovančević, S., Arbanas, Ž., Benac, Č. (2008) Assessment of Landslide Hazard on Flysch Slopes, Razprave petega posvetovanja slovenskih geotehnikov, Nova Gorica, SLOGED (Logar, J., Petkovšek, A., Klopčič J.ur). 263272. Ljubljana, Slovensko geotehniško društvo.

[26] Đomlija, P., Bernat, S., Mihalić Arbanas, S., Benac, Č. (2014) Landslide Inventory in the Area of Dubračina River Basin, Croatia, Landslide Science for a Safer Geoenvironment, Volume 2: Methods of Landslide Studies (Sassa, K.; Canuti, P.; Yin, Y. ur.), Switzerland. Springer International Publishing, 837-842.

[27] Zavod za prostorno uređenje Istarske županije, https://www.istra-istria. hr/fileadmin/dokumenti/prostorni_plan/Ostali/PPIZ_2016/PPIZ_2016S/ Kartogram_C_Karta_stanista_2016S.pdf, pristup 09.06.2019.

[28] Prostorni plan Primorsko-goranske županije, https://zavod.pgz.hr/docs/ zzpuHR/docsplanovizupanija/6/karte/karta-1.pdf, pristup 09.06.2019.

[29] Fell, R., Corominas, J., Bonnard, C., Cascini, L., Leroi, E. (2008) Savage WZ on behalf of the JTC-1 Joint Technical Committee on Landslides and Engineered Slopes Guidelines for Landslide Susceptibility, Hazard and Risk Zoning for Land Use Planning. Engineering Geology, 102: 85-98.

[30] Parkash, S. (2014) Geohazards Risk Management in India. National Institute of Disaster Management (India). 8th Asian Rock Mechanics Symposium. Sapporo, Japan. 